https://doi.org/10.17816/MAJ191S154-56

\title{
CLINICAL AND IMMUNOLOGICAL ASPECTS OF CHRONIC HEADACHES IN PATIENTS WITH SYSTEMIC LUPUS ERYTHEMATOSUS
}

\author{
N.V. Aleksandrova ${ }^{1}$, A.V. Aleksandrov ${ }^{1,2}$, I.Yu. Alekhina ${ }^{3}$, O.V. Paramonova ${ }^{2}$ \\ ${ }^{1}$ Institute for Clinical and Experimental Rheumatology named after A.B. Zborovsky, Volgograd, Russia; \\ ${ }^{2}$ Volgograd State Medical University, Volgograd, Russia; \\ ${ }^{3}$ Stavropol State Medical University, Stavropol, Russia

\section{КЛИНИКО-ИММУНОЛОГИЧЕСКИЕ АСПЕКТЫ ХРОНИЧЕСКОЙ ГОЛОВНОЙ БОЛИ У ПАЦИЕНТОВ С СИСТЕМНОЙ КРАСНОЙ ВОЛЧАНКОЙ} \\ Н.В. Александрова ${ }^{1}$, А.В. Александров ${ }^{1,2}$, И.Ю. Алехина ${ }^{3}$, О.В. Парамонова ${ }^{2}$ \\ ${ }^{1}$ ФГБНУ «НИИ КиЭР им. А.Б. Зборовского», Волгоград; \\ 2 ФГБОУ ВО «Волгоградский государственный медицинский университет» Минздрава РФ, \\ кафедра госпитальной терапии, Волгоград; \\ ${ }^{3}$ ФГБОУ ВО «Ставропольский государственный медицинский университет» Минздрава РФ, \\ кафедра госпитальной терапии, Ставрополь
}

imlab68@gmail.com

\begin{abstract}
Objective: to study the clinical and immunologica features of the manifestation of chronic pain in systemic lupus erythematosus (SLE) patients with neurological symptoms.

Methods. We examined 30 healthy individuals and 38 patients with SLE. Beck's depression questionnaire was used to assess the presence of depressive symptoms. Antibodies to adenosine deaminase (anti-ADA), $\beta_{2}$-glycoprotein-I-dependent antibodies to phospholipids of the IgG class (anti-FL) and antibodies to doublestranded DNA (anti-dsDNA) were determined in the serum of patients with SLE. Doppler sonography of the brachiocephalic arteries was performed for all patients with SLE.

Results. Complaints about the presence of headaches of varying severity presented 35 people $(92.1 \%)$. Migraine was recorded in $63.2 \%$ patients with SLE. Doppler ultrasound in patients with SLE with chronic headaches in $66.7 \%$ of cases showed signs of reduced blood flow in the arteries of the vertebrobasilar basin, which may indicate chronic brain ischemia. Signs of depressive disorder of varying severity were found in $36.8 \%$ of patients with SLE, and in patients with neurological disorders, moderate $(p=0.027)$ and severe $(p=0.041)$ depression were more often detected. Elevated levels of anti-ADA were found in 36.8\%, and anti-FL in 44.7\% of patients with SLE. It was noted that "migraine-like" manifestations of chronic pain syndrome were more common in the group of patients with SLE, who had a combined increase in anti-ADA and anti-FL $\left(\chi^{2}=4.5\right.$; $p=0.024)$. Since a certain part of ADA is concentrated in the plasma membranes of vascular and platelet endothelium cells, it can be assumed that there is a conformational effect of anti-ADA on the $\beta_{2}$-glycoprotein-I, leading to increased synthesis of anti-FL and undesirable activation of coagulation cascade in vessels.

Conclusion. The combination of severe chronic headache with high levels of anti-ADA and anti-FL can precede the development of stroke and transient ischemic attacks, which emphasizes the need for additional immunological examination of patients with SLE with neurological symptoms.
\end{abstract}

Keywords: systemic lupus erythematosus; chronic headache.

Цель - изучить клинико-иммунологические особенности проявления хронического болевого синдрома у больных системной красной волчанкой (СКB) с неврологической симптоматикой.

Meтоды. Обследовано 30 здоровых лиц и 38 пациентов с СКВ. Для оценки наличия депрессивных симптомов использовали опросник Бека. В сыворотке крови больных СКВ определяли антитела к аденозиндезаминазе (анти-АДА), $\beta_{2}$-гликопротеин-I-зависимые антитела к фосфолипидам класса IgG (анти-ФЛ) и антитела к двуспиральной ДНК (анти-dsДНК). Всем пациентам с СКВ была проведена ультразвуковая допплерография брахиоцефальных артерий.

Pезультаты. Жалобы на наличие головных болей различной степени выраженности предъявили 35 человек $(92,1 \%)$. Мигрень была зарегистрирована у 63,2\% больных СКВ. При проведении ультразвуковой допплерографии у больных СКВ с хронической головной болью в 66,7\% случаев были выявлены признаки снижения кровотока в артериях вертебрально-базилярного бассейна, что может свидетельствовать о наличии хронической ишемии мозга. Признаки депрессивного расстройства различной степени выраженности были выявлены у 36,8 \% больных СКВ, причем у пациентов с неврологическими нарушениями чаще определялась выраженная $(p=0,027)$ и тяжелая $(p=0,041)$ депрессия. Повышенные уровни анти-АДА обнаружены у 36,8 \%, а анти-ФЛ - у 44,7 \% больных СКВ. «Мигреноподобные» проявления хронического болевого синдрома чаще встречались в группе больных СКВ, у которых определялось сочетанное повышение анти-АДА и анти-ФЛ $\left(\chi^{2}=4,5 ; p=0,024\right)$. Учитывая, что определенная часть аденозиндезаминазы сосредоточена в плазматических мембранах клеток эндотелия сосудов и тромбоцитов, можно предположить наличие конформационного воздействия анти-АДА на $\beta_{2}$-гликопротеин-I, что может способствовать усилению синтеза анти-ФЛ и нежелательной активации коагуляционного каскада в сосудах. 
Заключение. Сочетание выраженной хронической головной боли с высокими уровнями антиАДА и анти-ФЛ может предшествовать развитию инсульта и транзиторным ишемическим атакам, что подчеркивает необходимость дополнительного иммунологического обследования больных СКВ с неврологической симптоматикой.

Ключевые слова: системная красная волчанка; хроническая головная боль.

Introduction. The development and improvement of non-invasive diagnostic methods can contribute to the early detection of neurological disorders in systemic lupus erythematosus (SLE).

Objective: to study the clinical and immunological features of the manifestation of chronic pain in SLE patients with neurological symptoms.

Materials and methods. We examined 30 healthy individuals and 38 patients with SLE who met the inclusion criteria (a reliable diagnosis of SLE, female, no older than 55 years old, no history of brain injuries and diseases of the central nervous system). SLE activity was monitored using the SELENA-SLEDAI index, a general assessment of the patient's condition by a doctor using a $100 \mathrm{~mm}$ visual analogue scale (VAS). Beck's depression questionnaire was used to assess the presence of depressive symptoms. Evaluation of the results was carried out in points. When conducting immunological tests, the object of research was blood serum. IgG antibodies to adenosine deaminase (anti-ADA) were determined in an indirect ELISA test developed by us using the immobilized form of ADA (the norm is less than $0.106 \mathrm{U}$ ) [1]; $\beta_{2}$-glycoprotein-Idependent antibodies to phospholipids of the $\operatorname{IgG}$ class (anti-FL) were determined using the "AntiPhospholipid Screen IgG/IgM" test kit (Orgentec, Germany) (up to $10 \mathrm{GPL}-\mathrm{U} / \mathrm{ml}$ ); antibodies to double-stranded DNA (anti-dsDNA) - test kit "Vecto-dsDNA-IgG" (Vector-Best, Russia) (up to $25 \mathrm{IU} / \mathrm{ml}$ ). Doppler sonography of the brachiocephalic arteries was performed for all patients with SLE on the Accuvix V10 ultrasound diagnostic system (Samsung Medison, South Korea) using a $5-12 \mathrm{MHz}$ linear transducer using a standard technique (the state of the blood flow was assessed by qualitative and quantitative characteristics). According to the indications, magnetic resonance imaging of the brain was performed.

Results and discussion. The average value of the SELENA-SLEDAI index at the time of the initial inspection was $12.8 \pm 4.4$ points). Complaints about the presence of headaches of varying severity presented 35 people (92.1\%). The following features of headaches were revealed in patients with SLE: occurrence in the morning hours $(34.2 \%)$, paroxysmal character $(26.3 \%)$, combination with vertigo (15.8\%) and sleep disorders $(47.4 \%)$. There was no relationship between the presence of cephalgia and disease activity $(p=0.16)$. Severe persistent chronic headache, including migraine, observed at the time of the initial examination or within 10 days preceding the examination, was recorded in $24(63.2 \%)$ patients with SLE. Migraine is a characteristic nosological form in the structure of neurological lesions in SLE, often proving to be the earliest manifestation of the disease. Doppler ultrasound in patients with SLE with chronic headaches in $66.7 \%$ of cases showed signs of reduced blood flow in the arteries of the vertebrobasilar basin, which may indicate chronic brain ischemia [2]. Signs of depressive disorder of varying severity were found in $36.8 \%$ of patients with SLE, and in patients with neurological disorders, moderate $(p=0.027)$ and severe $(p=0.041)$ depression were more often detected. Elevated levels of anti-ADA were found in $36.8 \%$, and anti-FL in $44.7 \%$ of patients with SLE. There was no significant correlation between the presence of headaches and the level of anti-dsDNA $(p>0.02)$, although there was a moderate positive correlation of anti-dsDNA with the duration of the disease $(r=0.41, p=0.028)$. It was noted that "migraine-like" manifestations of chronic pain syndrome were more common in the group of patients with SLE, who had a combined increase in anti-ADA and anti-FL, compared with patients who had an isolated increase in serum anti-FL $\left(\chi^{2}=4.5 ; p=0.024\right)$. Joint detection of anti-ADA and anti-FL in patients with SLE was also associated with manifestations of the cytopenic syndrome $(p=0.019)$. Since a certain part of ADA in the form of a complex with glycoproteins is concentrated in the plasma membranes of vascular and platelet endothelium cells, it can be assumed that there is a conformational effect of anti-ADA on the $\beta_{2}$-glycoprotein-I, leading to increased synthesis of anti-FL and undesirable activation of coagulation cascade in vessels.

Conclusion. Diagnosis of neurological disorders in SLE is often difficult, and clinical signs such as persistent headache and various sleep disorders are regarded by clinicians as functional. The combination of severe chronic headache with high levels of anti-ADA and anti-FL can precede the development of stroke and transient ischemic attacks, which emphasizes the need for additional immunological examination of patients with SLE with neurological symptoms.

\section{References}

1. Aleksandrov AV, Alekhina IY, Aleksandrov VA, et al. Antibodies to the enzyme of adenine branch of purine metabolism in patients with systemic lupus erythematosus. Annals of the Rheumatic Diseases. 2016;75(S2):1054.

2. Fajzulina DL, Shprah VV. Sosudistaja patologija golovnogo mozga u bol'nyh sistemnoj krasnoj volchankoj zhenshhin. Zhurnal nevrologii i psihiatrii im. S.S. Korsakova. 2013;113(3):4-8. 